\title{
Socio-Economic Implication of Political and Economic Participation of Women in Nigeria
}

\section{Faruq Umar}

Innovation and Technology Policy Department (ITPD), Nigerian Institute of Social and Economic Research (NISER), Ibadan, Nigeria.

Email:qufaruq@gmail.comTel:+2348053655874

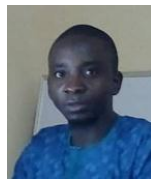

\begin{abstract}
This paper examined social-economic impacts of economic and political empowerment of women in Nigeria between 1990-2018. To achieve our main objective, we employed a trend analysis and ARDL technique with data sourced from the WDI (2019) and various issues of National Bureau of Statistics. We observed that the growth of women (between age 15 and 64) in labour force participation in Nigeria is trending downwardly during the period under consideration. While the proportion of female representation in the parliament has been on the increase since the advent of the fourth Republic in 1999. Finally, we unsurprisingly, discovered that despite the huge resources committed to advocacy for women's empowerment, the social costs in terms of the increased crime rate among youth and the level of insecurity in the country significantly overwhelmed the economic benefits in term of increased economic growth. Consequently, we inter alia recommended that the governments together with these advocacy groups should channel the same amount of resources devoted to campaigns for women empowerment into reversing the ugly trend of juvenile delinquency if the level of insecurity in Nigeria is to be curtailed. And, the proposed bill by the National Assembly and the 36 state Houses of Assemblies to increase the maternity leave from its current level of 3 months to 6 months should be fast-track and duly implemented across board in both public and private organizations.
\end{abstract}

Keywords: Women empowerment, Insecurity, Endogenous growth model, ARDL technique, Juvenile Delinquencies JEL Classification: J13; A 1; B23; C22; O11; O47.

Citation | Faruq Umar (2020). Socio-Economic Implication of Political and Economic Participation of Women in Nigeria. Economy, 7(1): 1-10.

History:

Ristory:

Revised: 18 February 2020

Accepted: 25 March 2020

Published: 21 April 2020

Licensed: This work is licensed under a Creative Commons

Attribution 3.0 License (c) $)$ Er

Publisher: Asian Online Journal Publishing Group
Funding: This study received no specific financial support.

Competing Interests: The author declares that there are no conflicts of interests regarding the publication of this paper.

Transparency: The author confirms that the manuscript is an honest, accurate, and transparent account of the study was reported; that no vital features of the study have been omitted; and that any discrepancies from the study as planned have been explained.

Ethical: This study follows all ethical practices during writing.

\section{Contents}

1. Introduction

2. Literature Review

3. Research Methodology

4. Results and Discussions

5. Conclusion

References 


\section{Contribution of this paper to the literature}

This study contributes to existing literature by examining social-economic impacts of economic and political empowerment of women in Nigeria between 1990-2018.

\section{Introduction}

\subsection{Background to Study}

Crime rate among Nigerian youths has assumed a worrisome dimension, today. If the current trajectory in crime rate among these youths is allowed to continue unabatedly, the future of Nigeria and its productive army is clearly on the path of destruction (see (Adebayo, 2013; Ajaegbu, 2012; Ajufo, 2013)). Nigeria is a developing country and it is no doubts currently experiencing rising crime waves, criminal intentions and varying degree of delinquencies. Nigeria has been on the global crime map since 1980 s (Dambazau, 2007). These crimes are in different dimensions that include armed robbery, murder, rape, religious radicalism, banditry, kidnapping, car theft, burglary, fraud, bribery and corruption, smoking and drug addiction, gambling, exam malpractices, smuggling, human trafficking, kidnapping, drug trafficking, terrorism, money laundering, internet scam, advanced fee fraud (419), cultism, 'aristo' among ladies just to mention a few (Aremu \& Ahmed, 2011). Sadly, these forms of crimes are committed mostly by the youth virtually in every nooks and crannies of the country. Criminality has become an integral part of the daily life of many of these youths who are supposed to be the ingredients required for the upliftment of the country amongst the comity of nations. This spate of crimes is capable of, if not already, undermining the corporate existence of the country as well as efforts towards sustainable growth and development (Tanimu, 2006). Security and crime have been deeply rooted in the political history of this country, particularly in the recent times, which has emerged as a key concept in Nigeria's struggle for good governance, sustainable democracy and development.

The main concept behind the formation of a state is security. The state therefore has the responsibility of maintaining law and order in the society and also to protect and defend the national integrity of the state. As enshrined in the 1999 Constitution of the Federal Republic of Nigeria the security and welfare of the people is the primary purpose of the government. However, it appears government has failed to provide a secured and safe environment for lives and property including the free conduct of economic activities. Since the return of the country to democratic rule, security of lives and property has been so threatened by these juvenile delinquencies that has manifest in various forms (Okafor, 2011; Onwuka, Ugwu, Chukwuma, \& Chijioke, 2015). In an attempt to contain these increasing waves of violent crime in Nigeria, the federal government has been committing huge budgetary allocation to security via the Federal Ministry of Defence and the office of the National Security Adviser to the president in its various forms since 1999. For example, the $8^{\text {th }}$ National Assembly of Nigeria comprises of the senate and House of Representative in 2018, gave an approval to a loan of about One Billion US dollars from international creditors to fight terrorism and other forms of crimes. All these monies are meant to purchase fighting equipment and organized special training for the security forces which is a trade-off for developmental strides. Meanwhile, the National Security Adviser (NSA) has continued to organize trainings for the military and para-military personnel both local and international in order to de-radicalize the youth and nip the insecurity in the bud. Despite these, it appears the level of violent crime in the country is still rife, and a confirmation of this is the low ranking (148/163) of Nigeria in the Global Peace Index (2019) and the United States of America put Nigeria on a watch list of potential terrorist countries in 2009.

Meanwhile, there are already avalanche of literature on the factors responsible for the rising crime rate in Nigeria, none seems to be focusing on the rising trend of women empowerment (see (Adebayo, 2013; Onwuka et al., 2015; Osawe, 2015)) as a possible causal factor. Little or no attention has been given to the impact of employed or politically active married women on the upbringing and nurturing of their children in our society. The campaign for women empowerment is getting stronger by the day by a number of advocacy groups but no one is really doing much to examine the implications of this on the social evolution of the children and youths. In reality, in a traditional African setting, family remains fundamental to caring for the old and the sick as well as the children who are the next generation, however, the modern society seems to steer more educated women from marriage and child bearing, giving zero attention to the abandonment of women's traditional roles notwithstanding the grave warning signs. Maternal support that are highly required by children while growing up are now deprived of due to full-time job obligations with increasing social vices and thereby affects the economic growth target, in the longrun. According to Laub and Sampson (1993) a mother-child relationship is a social and psychological resource from which the children draw as they grow in life. This relation is like a social investment or social capital, thus if politics or economic activities prevent mothers from investing in their children, it directly or indirectly results in negative consequences.

In this respect, this study intends to observe a trend analysis of political and economic participation of women in Nigeria and its implication on juvenile delinquencies. Thus, the main objective of the study is to investigate the social-economic implication of political/economic empowerment of women in Nigeria. To achieve our objectives, the following research questions are formulated: What are the observable trends in economic and political empowerment of women in Nigeria? Lastly, has empowerment of women exhibited any significant impact on socioeconomic growth in Nigeria? The rest of the paper is structured as follows: section two presents the review of literature on women empowerment and economic growth; section three presents the theoretical framework and research methodology; the empirical findings of the study are discussed in section four; and the final section presents the conclusion and policy recommendations.

\section{Literature Review}

\subsection{Factors Responsible for Economic Growth and Development}

Economists generally agree that economic development and growth are influenced by four factors: human resources, physical capital, natural resources and technology (see (Romer, 1990; Todaro, 1992)). Highly developed countries have governments that focus on these areas. Less-developed countries, even those with high amounts of 
natural resources, will lag behind when they fail to promote research in technology and improve the skills and education of their workers.

The skills, education and training of the labor force have a direct effect on the growth of an economy. A skilled, well-trained workforce is more productive and will produce a high-quality output that adds efficiency to an economy. A shortage of skilled labor can be a deterrent to economic growth. An under-utilized, illiterate and unskilled workforce will become a drag on an economy and may possibly lead to higher unemployment.

Improvements and increased investment in physical capital - such as roadways, machinery and factories - will reduce the cost and increase the efficiency of economic output. Factories and equipment that are modern and wellmaintained are more productive than physical labor. Higher productivity leads to increased output. Labor becomes more productive as the ratio of capital expenditures per worker increases. An improvement in labor productivity increases the growth rate of the economy.

The quantity and availability of natural resources affect the rate of economic growth. The discovery of more natural resources, such as oil or mineral deposits, will give a boost to the economy by increasing a country's production capacity. The effectiveness of a county at utilizing and exploiting its natural resources is a function of the skills of the labor force, type of technology and the availability of capital. Skilled and educated workers are able to use these natural resources to spur the growth of the economy.

Improvements in technology have a high impact on economic growth. As the scientific community makes more discoveries, managers find ways to apply these innovations as more sophisticated production techniques. The application of better technology means the same amount of labor will be more productive, and economic growth will advance at a lower cost. Countries that recognize the importance of the four factors that affect economic growth will have higher growth rates and improved standards of living for their people. Technological innovation and more education for workers will improve economic output which lead to a better living environment for everyone. Increases in labor productivity are much easier to achieve when investments are made on better equipment that require less physical work from the labor force (Grossman \& Helpman, 1991; Romer, 1990).

\subsection{Recent Political Landscape in Nigeria: Women Participation in Nigeria Politics}

Women are reported to form 49.4 per cent of Nigeria's population (NBS, 2017). However, female political representation in the just concluded 2019 general elections is negligible relative to the approximately half of the population they constitute. According to the INEC (2019) 2019 general election reports; only 62 women out of the 2,970 who contested for different political offices in the 2019 general elections got elected into the various offices they vied for. Apart from the 1999 election which signaled the birth of the fourth Republic in Nigeria that saw women occupying 15 seats in the National Assembly - three in the Senate and 12 in the House of Representatives the number of elected female lawmakers has never been this poor in any other election at the federal level. Although, there is currently the affirmative action of $35 \%$ representation of women in political and non-elective positions in Nigeria, the number of women in the legislative houses is not so encouraging as a result of the patriarchal dominance of the men in Nigeria.

In the elective positions in Nigeria since 1999, it is evident that women have not reached $10 \%$ representation. From 1999 till date, no woman has been vice president of Nigeria and not to talk of being the president. In 2011 for instance, only one woman contested for the post of the president in Nigeria under the platform of the People's Democratic Party and she did not survive the primary election. In 2015, 5 women out of the 14 contestants contested for the vice-presidential position while 14 men contested the post of president. The number of women elected to public offices in Nigeria did not increase after the 2019 election. Instead, there was a decline to any progress made in women's previous outings since the inception of the fourth Republic, this is evident from Table 1, below.

In the 2019's National Assembly election, 235 women, forming 12.34 per cent of candidates, contested for seats in the Senate of which seven (6.42 per cent) were elected. This remained constant in the 8 th Senate, which also accounted for 6.42 per cent of the total number of elected senators.

In the House of Representatives, 533 women contested and only 11 (3.05 per cent) got elected. The record from the 8 th assembly has thus been halved, as it had 22 female lawmakers.

Table-1. Statistics of women elective office holders since the inception of the fourth republic.

\begin{tabular}{l|l|c|c|c|c|c|c|c}
\hline S/N & Position & No of Seats & $\mathbf{1 9 9 9}$ & $\mathbf{2 0 0 3}$ & $\mathbf{2 0 0 7}$ & $\mathbf{2 0 1 1}$ & $\mathbf{2 0 1 5}$ & $\mathbf{2 0 1 9}$ \\
\hline 1 & Presidency & 1 & 0 & 0 & 0 & 0 & 0 & 0 \\
\hline 2 & Vice President & 1 & 0 & 0 & 0 & 0 & 0 & 0 \\
\hline 3 & Governors & 36 & 0 & 0 & 0 & 0 & 0 & 0 \\
\hline 5 & Senate & 109 & $3(2.8 \%)$ & $4(3.7 \%)$ & $9(8.3 \%)$ & $7(6.4 \%)$ & $7(6.4 \%)$ & $7(6.4 \%)$ \\
\hline 6 & $\begin{array}{l}\text { House of } \\
\text { Representative }\end{array}$ & 360 & $\begin{array}{c}12 \\
(3.3 \%)\end{array}$ & $21(5.8 \%)$ & $26(7.2 \%)$ & $25(6.9 \%)$ & $19(5.2 \%)$ & $11(3.1 \%)$ \\
\hline 7 & $\begin{array}{l}\text { States Houses of } \\
\text { Assembly }\end{array}$ & 990 & $24(2.4 \%)$ & $40(3.9 \%)$ & $57(5.8 \%)$ & $68(6.9 \%)$ & $54(4.6 \%)$ & $40(4.0 \%)$ \\
\hline
\end{tabular}

\subsection{Review of Empirical Studies}

Ehigie and Umoren (2003) examined the psychological factors influencing entrepreneurial success among Nigerian women in small-scale businesses. The study focused on self-concept, perceived managerial competence, and work stress and business commitment as important psychological variables for entrepreneurial success among female entrepreneurs. The study concludes that success for female entrepreneurs relies on a high self-concept regarding their role in business, commitment to business and reduction of a conflict between home responsibilities and business. Finally, the study recommends training programs as essential for effective business management among women entrepreneurs. Ekpe (2011) conducted a study on "Women Entrepreneurs and Economic Development in Nigeria: Characteristics for Success". Using women entrepreneurs who were clients of 4 microfinance institutions in the Northern region of Nigeria, the study found that motivation, foresight and achievement are vital characteristics for success; and that women entrepreneurs in Nigeria possess the necessary characteristics 
for entrepreneurial success. Ekesionye and Okolo (2012) examined women empowerment and participation in economic activities as indispensable tools for self-reliance and development of Nigeria. Using 351 randomlyselected women respondents in Anambra State, it was found that the major economic activities of women in the area included farming, trading, craft, food processing, hair dressing and poultry. Their sources of fund include personal savings, family assistance, philanthropist's assistance, loans and credits, cooperative society assistance, and group contributions (esusu). Inability of government to provide support, corruption on the part of implementers, family burden, cultural restrictions, husband influence and illiteracy were the obstacles women encounter in carrying out their economic activities. In a related development, Fapohunda (2012) carried out a study on Women and the Informal Sector in Nigeria: Implications for Development. The study was based on library sources and a field survey of 150 women in the Mushin, Agege and Lagos Island Areas of Lagos, Nigeria. He observed that employment opportunities in the formal sector are often denied women because of family responsibilities, lack of skills, social and cultural barriers; the informal sector is often the only possibility for women to get access to employment and to earn an income. Consequently, women dominate the informal sector, necessitating why policies and developments affecting the informal economy thus have a distinctly gendered effect. The paper argued that the informal sector has a high labour-absorption capacity and there is the need to increase the level of stimulation of employment opportunities.

\subsection{Theoretical Review}

2.4.1. The Gender Empowerment Theory.

This theory assumes that nations, businesses, communities, and groups can benefit from the implementation of programs and policies that adopt the notion of women empowerment (Deneulin \& Shahani, 2009). The empowerment language can actually lead to raised awareness (Rappaport, 1986). Empowerment can be understood by examining the concepts of power and powerlessness (Moscovitch \& Drover, 1981). Power is defined by the Cornell Empowerment Group as the "capacity of some persons and organizations to produce intended, foreseen and unforeseen effects on others" (Cornell Empowerment Group, 1989). There are many sources of power. Personality, property/wealth, and influential organizations have been identified by Galbraith and Schendel (1983) as critical sources of power in the last part of 21 stcentury. Others have pointed out that the class-dominated nature of our society means that a small number of people have vast economic or political power, while the majority has little or none (Moscovitch \& Drover, 1981).

According to Wallerstein (1992) empowerment is a social-action process that promotes participation of people, organizations, and communities towards the goals of increased individual and community control, political efficacy, improved quality of community life, and social justice.

Gender empowerment can be measured through the Gender Empowerment Measure (GEM). The GEM shows women's participation in a given nation, both politically and economically. GEM is calculated by tracking the share of seats in parliament held by women; of female legislators, senior officials and managers; and of female profession and technical workers; and the gender disparity in earned income, reflecting economic independence. It then ranks countries given this information. Other measures that take into account the importance of female participation and equality include the Gender Parity Index and the Gender-related Development Index (Deneulin \& Shahani, 2009).

\subsubsection{The U-Shape Hypothesis}

The U-shaped hypothesis is a stylized description of the relationship between the female labor force participation rate with economic development, which is typically measured in terms of GDP per capita. In its basic form, the hypothesis posits that female participation rates are highest in poor countries, where women are engaged in subsistence activities, and fall in middle-income countries because of the transition of (mainly) men to industrial jobs. As education levels improve and fertility rates fall, women are able to join the labor force in response to growing demand in the services sector. This is a stylized fact, but it is not robust to different data sets and econometric methodologies. While some countries follow this path, many labor markets do not exhibit this Ushaped relationship.

According to Verick (2018) as society develops and begins to shift to a more industrialized economy, women's opportunities for employment decrease. Family production aimed at self-consumption decreases and most consumed goods are produced outside the home, making it more difficult for women to reconcile childcare and work. Moreover, technical change requires employees with a higher level of education and the capacity to use machines, diminishing women's employment opportunities, and thus, their labour participation. This process is reinforced by the existence of social norms that dictate that women are responsible for domestic chores and stigmatize female participation in the workforce, making it difficult for women to work in the manufacturing industry. However, with the subsequent expansion of the service industry and the associated increase in female levels of education, new opportunities of employment for women are created. This, together with their higher wages, increases the opportunity cost of staying at home and reduces fertility rates. During this process, both income and substitution effects take place (Goldin \& Kanellakis, 1995).

\section{Research Methodology}

This section is divided into three sections; the first part presents the source of data and description of variables; the second section depicts the theoretical framework while the last section contains estimation techniques employed in the study.

\subsection{Data Sources and Description}

The data are sourced from the World Development Indicators (WDI, 2019) of the World Bank Group and the National Bureau of Statistics (NBS, 2013, 2018) of Nigeria. The WDI database with focus on the Gender Statistics consists of more than 500 indicators on topics such as economic growth, education, population, environment and natural resources, national accounts, social policy statistics, development assistance, for over 200 countries from 
1960 to 2018. The choice of a times series data analysis was premised on the nature of our database while the rationale behind the adoption of WDI database was based on the availability of a wide range of indicators. Specifically, the study utilized data on female labour force, political participation of women, gross domestic product and gross capital formation as the relevant macroeconomic performance indicators from WDI database while data on child delinquencies were from the (NBS, 2013, 2018). Table 2 describes the various variables employed in our analysis.

Table-2. Description of Variables.

\begin{tabular}{l|l}
\hline Dependent Variables & Variable description \\
\hline LRGDP & Natural log of gross domestic product from (1990-2018). \\
\hline Independent Variables & $\begin{array}{l}\text { Natural log of the interactive factor (LJDLLF) (i.e., interaction of female } \\
\text { labour force participation (FLFP) and juvenile delinquency (JDL) (1990 - } \\
2018)\end{array}$ \\
\hline LJDLLF & Natural log of gross capital formation (1990-2018). \\
\hline Control Variables & Female labour force participation (1990 - 2018) \\
\hline LGCF & Juvenile delinquency (1990-2018) \\
\hline FLFP
\end{tabular}

\subsection{Analytical Framework}

Adopting and modified the endogenous growth model by Romer (1990) with significant contributions from Grossman and Helpman (1991) and Aghion and Howitt (1992) by incorporating realities into the model.

The endogenous growth model is the AK production function; a special case of a Cobb-Douglas production function:

$$
\mathrm{Y}=\mathrm{A} K^{\alpha} \mathrm{L}^{1-\alpha}
$$

Where:

$\Upsilon=$ the total production in an economy.

$A=$ effectiveness of labour.

$K=$ capital.

$L=$ labor.

and the parameter $\alpha$ measures the output elasticity of capital.

\subsection{The Underlying Assumptions of Our Study from Reality}

There is a good producing sector.

$$
\begin{array}{r}
\mathrm{Y}=\mathrm{AK}^{\alpha} \mathrm{L}^{1-\alpha} \\
\mathbf{0}<\alpha<1
\end{array}
$$

Equation 2 implies constant returns to scale for labour and capital

We assume the labour factor $(\mathrm{L})$ in the model can be decomposed into 2: female labour force $\left(\mathrm{L}_{\mathrm{f}}\right)$ and male labour force $\left(\mathrm{L}_{\mathrm{m}}\right)$. That is, $\mathrm{L}=\mathrm{L}_{\mathrm{m}}+\mathrm{L}_{\mathrm{f}}$.

It has been established in the literature that crime rate among children and youth is a positive function of female labour participation and negative function of income (Verick, 2018). As a result, the increased female labour force participation leads to increase in crime rate among children and youth. The consequences of the increased crime rates among children will eventually affect father's concentration at work and leads to loss of male productive hours as well as income and thereby affects economic growth.

$$
\text { Hence, } \mathrm{JDL}=f\left(\mathrm{~L}_{\mathrm{m}} \mathrm{RGDP}\right) \text {. This can be written explicitly as } \mathrm{JDL}=\mathrm{YL}_{\mathrm{m} .}(4)
$$

$$
\text { From Equation 4, } \mathrm{L}_{\mathrm{m}}=\mathrm{JDL} / \mathrm{Y}
$$

Then, substitute Equations 4 and 4a into 2 and take the natural $\log$ of both sides.

$$
\ln \mathrm{Y}=\ln \mathrm{A}+\alpha \ln \mathrm{K}+(1-\alpha) \ln \left(\mathrm{JDL} / \mathrm{Y}+\mathrm{L}_{\mathrm{f}}\right)
$$

$$
\text { Thus, } \Upsilon=\beta_{0} A+\beta_{1} K+\beta_{2} \text { LJDLLF }
$$

From (5) is either $\beta_{2}<0$ or $\beta_{2}>0$, depending on the size of the net contribution of FLFP to the economic growth and reduction in economic growth due to loss in productive hours of male labour force participation. That is, if impact of FLFP is greater than impact of JDL, $\beta_{2}>0$ and otherwise, $\beta_{2}<0$. Thus, Equation 5 is the model of our study.

\subsection{Analytical Techniques}

To achieve the first objective of the study, trend analyses of female labour force participation and political participation were conducted using data from the WDI (2019). And the second and final objective of the study is achieved using the ARDL Bound Test technique. The ARDL Bound Test technique is employed to determine the long run relationship if any, between series with different order of integration (Pesaran, Shin, \& Smith, 1999; Pesaran., Shin, \& Smith, 2001). The reparameterized result gives the short-run dynamics and long run relationship of the considered variables. Although ARDL cointegration technique does not require pre-testing for unit roots, to avoid ARDL model crash in the presence of integrated stochastic trend of I(2), we therefore conducted unit root tests to determine the number of unit roots in the series under consideration.

The functional form of the model used to investigate the social implication of economic and political empowerment of women in Nigeria is therefore specified as:

$$
\text { LRGDP = f(LGCF, LJDLLF })
$$

Where LRGDP = natural log of gross domestic product; LGCF = natural log of gross capital formation, LJDLLF = natural log of the interactive factor (LJDLLF) (i.e., interaction of female labour force participation (FLFP) and juvenile delinquency (JDL)) This is incorporated in the model as a relevant explanatory, control variable).

$$
\text { LRGDP }=\alpha_{0}+\alpha_{1} \mathrm{LGCF}+\alpha_{2} \mathrm{LJDLLF}+U_{\mathrm{t}}
$$


Where $\mu=$ residual term. The $\alpha$ 's represents the long run parameters.

Thus, the general ARDL model follows the following equation:

$$
\Delta \mathrm{LRGDP}_{\mathrm{t}}=\alpha_{0 \mathrm{t}}+\sum \beta_{11} \Delta \mathrm{LRGDP}_{\mathrm{t}-1}+\sum \beta_{12} \mathrm{LJDLLF}_{\mathrm{t}-1}+\sum \beta_{13} \Delta \mathrm{LGCF}_{\mathrm{t}-1}+U_{1 \mathrm{t}}
$$

Where, $\left(\Delta \mathrm{LRGDP}\right.$ and $\left.\Delta \mathrm{LRGDP}_{\mathrm{t}-1}\right)$ are the dependent variables in first-difference and level, and $(\Delta \mathrm{LFLFP}$, $\triangle \mathrm{LGCF}_{\mathrm{t}-1}$ and $\left.\mathrm{LFLFP}, \mathrm{LGCF}_{\mathrm{t}-1}\right)$ are the independent variables in the model in first-differences and levels. Indeed, the $\alpha_{0}$ is the intercept, $\beta_{11 \ldots} \beta_{15}, \phi_{1 \ldots} \phi_{5}$ are the parameters of variables and $U$ is the error term of the model.

\section{Results and Discussions}

\subsection{Economic and Political Empowerment of Women and Economic Development in Nigeria}

This subsection presents the results of the trend analysis of women's empowerment in Nigeria from 1990 to 2018 and its implications for economic growth. In order to underscore the context of the study, the discussion starts with an overview of the trends in female labour force participation (FLFP) and the proportion of women in parliament from 1990 to 2018. To juxtapose the trend in women's empowerment in Nigeria, the following three largest economies in Africa (South Africa, Egypt and Algeria) and the BRICS countries (Brazil, Russia, India, China and South Africa) are selected for the comparative analysis. The BRICS are emerging economies with regional dominance but were similar to Nigeria in economic performance in the 1960's when Nigeria gained political independence. Four of the BRICS countries are also characterized by large population like Nigeria.

\subsubsection{Trends Analysis of Female Labour Force Participation 1990 - 2018}

Figure 1 shows female labour force participation in Nigeria by taking a look at the proportion of women that participate in paid employment. It reveals that proportion of Nigeria's women in labour force dwindled throughout the period under review. The average proportion for instance, was 35.4 per cent 1990-1994 but in 2015-2018 it is found to be 21.3 per cent. That is, despite the advocacy towards women's empowerment, the trend is not even on the rise. While within the same period, only Brazil recorded some level of appreciation in FLFP from approximately 46 per cent to 48 percent. Egypt remains constant over the entire period but surprisingly China, India and South Africa like Nigeria were equally on the decline. This shows that in the majority of the countries understudied, the trend of female labour force participation is even still on the decline in spite of the amount of capital outlays for women's empowerment advocacy in both developed and developing economies. This view is corroborated by the finding of Verick (2018) that shows that though more than 307 million women have joined the labor market in the past 20 years, women still account for just $39.2 \%$ of the global labor force.

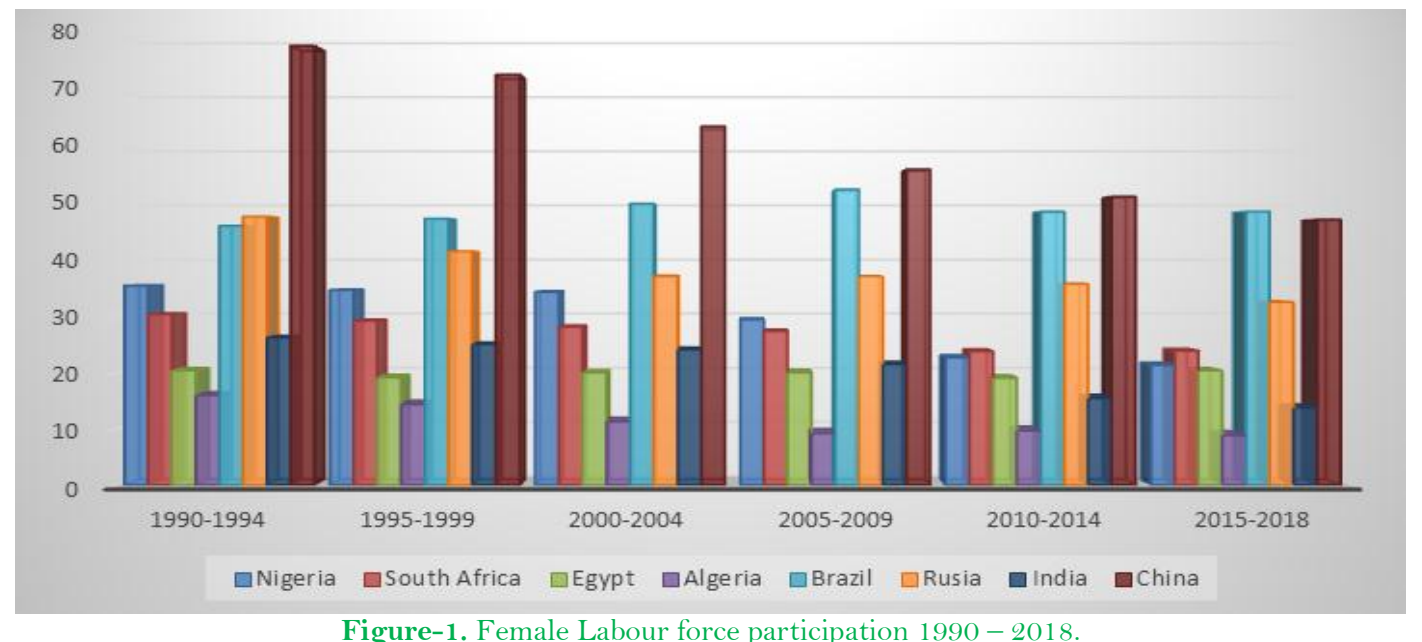

Source: WDI (2019).

\subsubsection{Proportion of Female in Parliament}

Figure 2 shows the Proportion of Female in Parliament in Nigeria by taking a look at the proportion of women that are elected into parliaments to participate in legislative activities at the national level. It reveals that proportion of Nigeria's women that involves in parliamentary activities in Nigeria is on the increase though with a slight decrease at the tail end of the period under review. The average number of women in parliament in Nigeria for instance, was approximately 4 per cent in 1999-2003 and increased to almost 7 percent in 2011-2015 but declined slightly in 2015-2019 (see (INEC, 2019)). Thus, it is obvious that political participation of women in Nigeria has been on the rise since the inception of the fourth Republic in Nigeria. Comparatively, for instance, women representation in Algeria shows the highest increase from approximately 5 per cent in 2000-2004 to roughly 30 per cent between 2015 and 2018 and, followed by South Africa from 30 per cent to around 42 per cent within the same period. Egypt moved from 2 per cent to above 12 per cent under same period. 


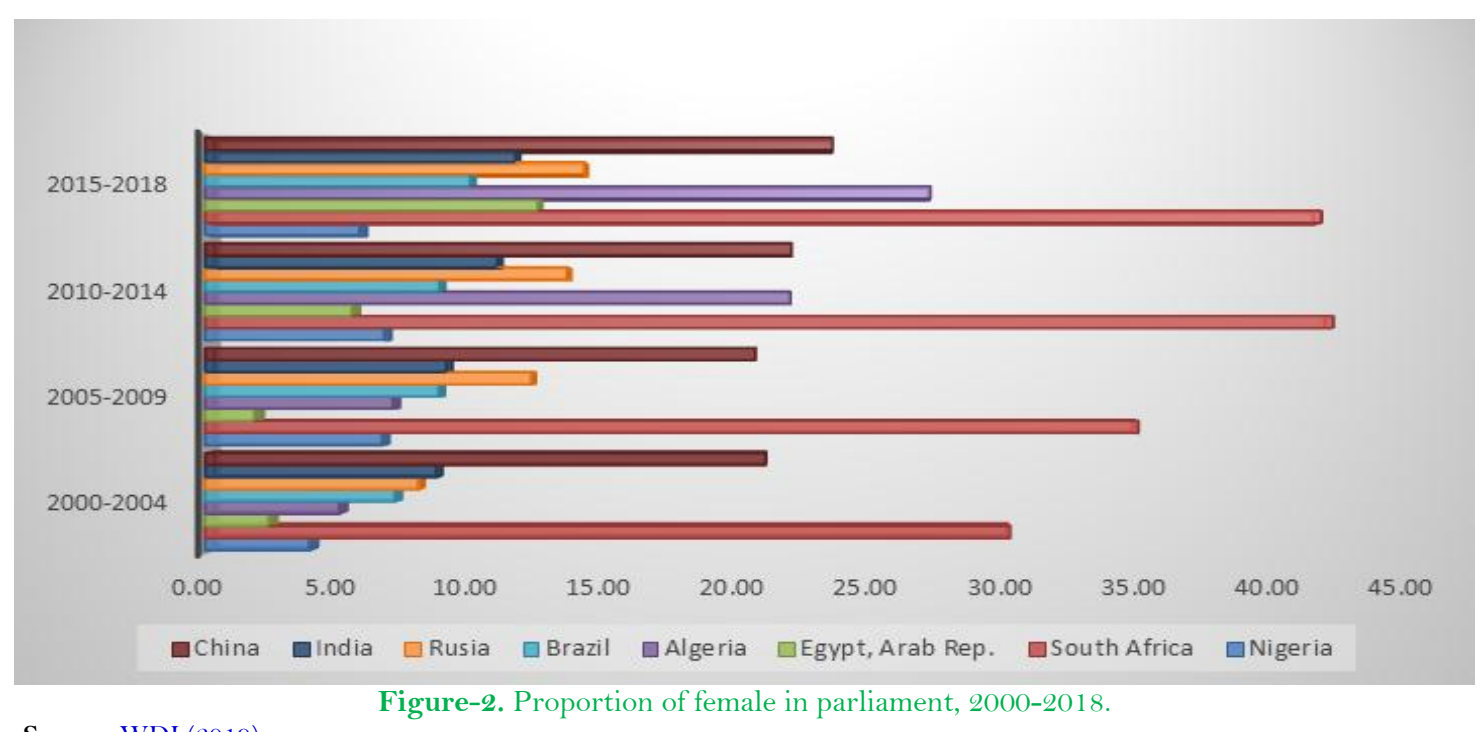

Source: WDI (2019).

\subsection{Social Implications of Economic and Political Empowerment of Women in Nigeria 4.2.1. Descriptive Statistics}

The statistical features of the data under consideration including the mean, the minimum and maximum values, standard deviations, kurtosis, skewness and the Jacque-Bera for the data in their levels. The descriptive statistics provide a historical background for the behaviour of our data. Table 3 details the descriptive statistics for each series.

Table-3. Descriptive Statistics

\begin{tabular}{l|c|c|c|c|c}
\hline Ttatistics & LRGDP & LGCF & LFLFP & LJDL & LJDLFP \\
\hline Mean & 7.500684 & 3.242562 & 3.878085 & 11.60285 & 44.99748 \\
\hline Median & 7.4915 & 3.28009 & 3.8622 & 11.7483 & 45.47013 \\
\hline Maximum & 7.852513 & 3.938836 & 3.921072 & 12.35469 & 47.66205 \\
\hline Minimum & 7.204986 & 2.638039 & 3.852891 & 10.44242 & 40.27585 \\
\hline Variance & 0.0569777 & 0.1917075 & 0.000622 & 0.273608 & 4.215786 \\
\hline Std. Dev. & 0.2387 & 0.4378441 & 0.0249391 & 0.5230755 & 2.053238 \\
\hline Skewness & 0.14224 & -0.0077698 & 0.663158 & -0.5802762 & -0.8673573 \\
\hline Kurtosis & 1.39008 & 1.555577 & 1.773855 & 2.375225 & 2.655757 \\
\hline Observations & 116 & 116 & 116 & 116 &
\end{tabular}

\subsubsection{Unit Root test}

The results of the unit root test Table 4 shows that all the series under study have unit root, i.e they are nonstationary as depicted in Table 4 below. In particular, all specifications of ADF (with trend or drift) and PP tests could not reject the null hypothesis of a unit root process, even at a $10 \%$ significance level for all the variables at level. When the series in first difference are tested, the null hypothesis of a unit root process is rejected at 1 per cent significance level except for the LFLFP; according to all specifications of ADF and PP tests. Therefore, ADF and PP unit root tests conclusively show that all variables of study are I(1) except the FLFP that is I $(2)$.

Table-4. Unit Root test.

\begin{tabular}{|c|c|c|c|c|c|c|}
\hline \multirow{3}{*}{ Variable } & \multicolumn{4}{|c|}{ Augmented Dickey-Fuller } & \multirow{2}{*}{\multicolumn{2}{|c|}{ Phillips-Perron Statistic }} \\
\hline & \multicolumn{2}{|c|}{ With Trend } & \multicolumn{2}{|c|}{ With Drift } & & \\
\hline & Level & First Diff. & Level & First Diff. & Level & First Diff. \\
\hline LRGDP & -1.884 & $-3.136^{* *}$ & -0.461 & $-3.201^{*}$ & -2.166 & $-3.862^{* *}$ \\
\hline LGCF & -2.791 & $-4.84^{*}$ & -1.187 & $-4.822^{*}$ & -2.139 & $-5.956^{*}$ \\
\hline LFLFP & -1.865 & -1.598 & -0.516 & -1.961 & -1.826 & -1.981 \\
\hline LJDL & -2.437 & $-4.92^{*}$ & $-2.536^{* *}$ & $-4.897 *$ & -2.032 & $-6.034^{*}$ \\
\hline LJDLFP & -2.499 & $-4.926^{*}$ & $-2.545^{*}$ & $-4.909 *$ & -2.073 & $-6.04 *$ \\
\hline
\end{tabular}

\subsubsection{ARDL Bounds Test of Cointegration}

In this study, after determining the unit root characteristics of the variables, the bounds test of cointegration was conducted in order to analyse the long-run relationship between the variables. Table 5 reports the estimated F-statistics values for the models. The second row in the table represents the optimal lag length for the model, which was selected using the AIC criterion.

The table shows no evidence of cointegration in the model. This implies that there is no long-run relationship between the selected variables. For instance, the estimated F-statistics value for the model is 2.393 , which is below the lower bound $\mathrm{I}(\mathrm{O})$ critical values provided by Pesaran. et al. (2001) at 1\%. That is, it is not significant and thus, we cannot reject the null hypothesis of no cointegration. Hence, we estimate a short-run model that is the ARDL equation rather than the ARDL long-run equation.

From Table 6 below, the sign of coefficient reported for LJDLFP is positive and statistically significant. This implies that female labour participation directly leads to increase economic growth (GDP) but the increased female labour participation also leads to a rise in the juvenile delinquencies (JDL) and thereby, reduced the expected net increase in economic growth (GDP). That is, the increased economic growth due to increased female labour force participation is less than the expected increase. Thus, it is inferred that the social costs of economic and political participation of women in terms of the increased crime rate among youths and the level of insecurity in the country 
overwhelms the economic benefits in term of increased economic growth. Meanwhile, for the gross capital formation (LGCF), though not surprising, the sign of the coefficient is negative but significant. This may be due the fact that there is a negative growth in capital formation (obsolete and depreciation) in many African countries which results in a decrease in economic growth (see Onyinye, Idenyi, and Ifeyinwa (2017)).

\begin{tabular}{l|c|c|c}
\multicolumn{4}{c}{ Table-5. Cointegration Results. } \\
\hline Estimated Model & \multicolumn{3}{|c}{ LRGDP (LGCF, LJDLFP) } \\
\hline Optimal Lag Length & $(2,1,2)$ & & \\
\hline F-Statistics (Bound Test) & 2.393 & & \\
\hline Critical values & $1 \%$ & $5 \%$ & $10 \%$ \\
\hline Lower Bound I(0) & 5.15 & 3.79 & 3.17 \\
\hline Upper Bound (1) & 6.36 & 4.85 & 4.14 \\
\hline R-Squared & 0.6637 & & \\
\hline Adj. R-Squared & 0.6415 & & \\
\hline F-Statistics & $421.8166^{*}$ & & \\
\hline
\end{tabular}

Note: *,**, and *** represents significance at the $1 \%, 5 \%$, and $10 \%$ levels, respectively. The Akaike Information

Criterion (AIC) criterion is used to determine the optimal lag. The critical values are determined from Pesaran. et al. (2001).

Table-6. Estimated coefficients of Autoregressive Distributed Lag ARDL (2,1,2) long-run results.

\begin{tabular}{c|c|c|c}
\hline Variables & Coefficients & Standard Error & t-statistic \\
\hline LRGDP (-1) & $1.682376^{*}$ & 0.0658449 & 25.55 \\
\hline LRGDP (-2) & $-0.6977592^{*}$ & 0.064128 & -10.88 \\
\hline LGCF & $-0.0493248^{*}$ & 0.020248 & -2.44 \\
\hline LGCF (-1) & $0.0406982^{*}$ & 0.0203099 & 2 \\
\hline LJDLFP & $0.0040157^{*}$ & 0.0014992 & -2.68 \\
\hline LJDLFP (-1) & -0.006892 & 0.0025079 & 2.25 \\
\hline LJDLFP (-2) & 0.0032659 & 0.0014542 & 1.34 \\
\hline Constant & 0.1264991 & 0.0945996 & Criterion
\end{tabular}

(AIC) criterion is used to determine the optimal lag. The critical values are determined from Pesaran. et al. (2001).
(20rmation

\subsection{Model Stability Test}

The stability of estimated model enhances its reliability for policy. We test the stability of the model with the plots of the cumulative sum of recursive residuals (CUSUM6). The plot is shown in Figure 3 below.

It can be observed that the plot of the CUCUSUMSQ lies between the straight lines representing critical bounds at $5 \%$ significance level. This suggests that the (parameters of the) models are structurally stable, and hence the models could be relied upon for policy formulation.

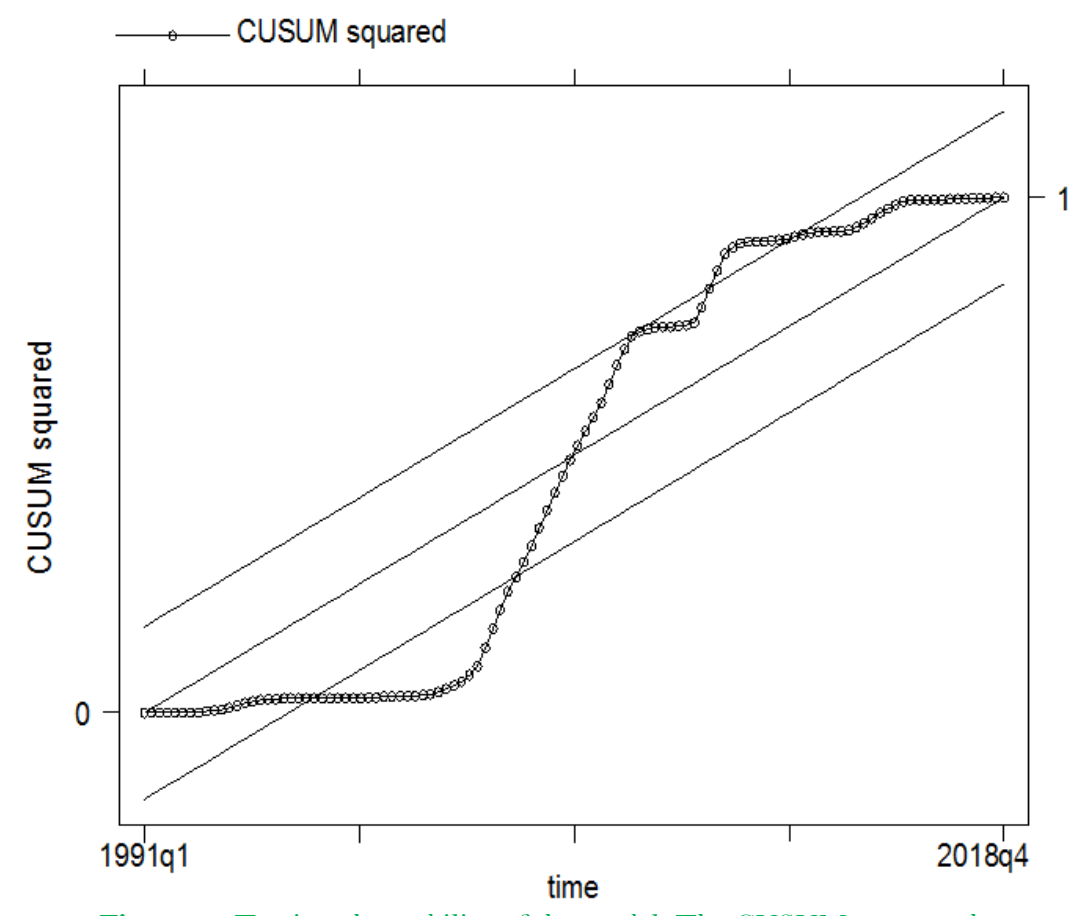

\section{Conclusion}

This study examined social implication of economic and political empowerment of women in Nigeria between 1990 and 2018 from the standing point of the often neglected but not too palatable effect of female labour force participation on children, adolescent, family and the society at large.

We estimated trend analyses and ARDL estimator with inclusion of control variables. We observed that proportion of Nigeria's women (between age 15 and 64) in labour force is on a downward trend between year 2000 and 2018. The mean values for instance, was 35.4 per cent 1990-1994 but in 2015-2018 it is found to be 21.3 per cent. On the political participation captured by the proportion of female representation in the parliament, we found that proportion of Nigeria's women that involves in parliamentary activities in Nigeria has been on the increase since the advent of the fourth Republic in 1999. The average number of women in parliament in Nigeria for instance, was approximately 4 per cent of total members of parliament in 1999-2003 which increased to almost 7 
percent in 2011-2015 but with a slight fall to about 6 per cent in 2015-2019. Many factors such as increasing education of women, cost of living, attractive political largesse, family responsibilities to mention a few are among the factors responsible for this rising trend among women folks. For the realized increased incomes from female labour participation, the entire society have completely jettisoned the attendant negative impact of women influx into labour market on the society at large.

Finally, we observed that the increased economic growth due to increased female labour force participation is less than what it ought to be. This implies that in spite of the resources committed to campaigns for economic and political empowerment of women, the social costs in terms of the increased crime rate among youths and the accompanied level of insecurity in the country in general still significantly overwhelmed the economic benefits in term of increased economic growth. Unfortunately, the gains from women employment are rarely noticed to be also accompanied by social losses. The poor upbringing and supervision of children due to female labour participation increases the probability of delinquency as a result of low self-control (see (Adebayo, 2013; Burt, 2019; Vazsonyi, Jiskrova, Ksinan, \& Blatný, 2016)). Succinctly, this study successfully confirms a seemingly positive correlation between political/economic empowerment of women and economic growth but these economic gains are indirectly eroded by criminal activities among children and the youth.

Flowing from the conclusions of the study, the following recommendations are proposed:

i. The government as well as advocacy groups must channel the same efforts and resources devoted to campaigns for women empowerment into reversing the ugly trend of juvenile delinquency if the level of insecurity in the Nigeria is to curtail.

ii. To stem this ugly slide, the proposed bill by the National Assembly and the 36 state Houses of Assemblies to increase the maternity leave from its current level of 3 months to 6 months should be fast-track and duly implemented across board in both public and private organizations. Though, this is already being implemented in one or two states of the federation (e.g Kaduna).

iii. Our women need training and re-training (parent education) on child rearing responsibilities for them to appreciate the importance of their traditional role on the society at large.

iv. There is a need for the government to further strengthen all the agencies (e.g NAPTIP, NDLEA) that are in charge of comprehensive national programs for the prevention and detection of all forms of physical, drug and sexual abuses of children and the rehabilitation of those that have already been abused.

v. Governments at all levels need to ensure that all the youth who are deprived of a family and parental cares (e.g Alimajiris in the North and Area Boys in the South) have access to appropriate forms of alternative cares where their rights are fully safeguard.

vi. Incentives should be provided by the government and other stakeholders to encourage women to take up only formal jobs which do not interfere with their domestic responsibilities and their bonds with the children.

\section{References}

Adebayo, A. A. (2013). Youths' unemployment and crime in Nigeria: A nexus and implications for national development. International Journal of Sociology and Anthropology, 5(9), 350-357.Available at: https://doi.org/10.5897/ijsa2013.0452.

Aghion, P., \& Howitt, P. (1992). A model of growth through creative destruction. Econometrica, 60(2), 323-351.Available at: https://doi.org/10.2307/2951599.

Ajaegbu, O. O. (2012). Rising youth unemployment and violent crime in Nigeria. American Journal of Social Issues and Humanities, 2(5), 315321.

Ajufo, B. I. (2013). Challenges of youth unemployment in Nigeria: Effective career guidance as a panacea. African Research Revierw, 7(1), 307321.Available at: https://doi.org/10.4314/afrrev.v7i1.21

Aremu, M. A., \& Ahmed, Y. A. (2011). An investigation of security and crime management in developing society: The implications for Nigeria democratic set-up. International Journal of Academic Research in Business and Social Sciences, 1(3), 390-399.

Burt, C. (2019). Self-control and crime: Beyond gottfredson and Hirschi's theory. Annual Review of Criminology, 3(1), 43-73.

Cornell Empowerment Group. (1989). Empowerment and family support. Networking Bulletin, 1(2), 1-23.

Dambazau, A. (2007). The Nigerian police and crime prevention: Criminology and criminal justice Nigerian. Kaduna: Defense Academy Press.

Deneulin, S., \& Shahani, L. (2009). An introduction to the human development and capability approach: Freedom and agency (pp. 1-354): IDRC.

Ehigie, B. O., \& Umoren, U. E. (2003). Psychological factors influencing perceived entrepreneurial success among Nigerian women in smallscale businesses. Journal of International Women's Studies, 5(1), $78-95$.

Ekesionye, E., \& Okolo, A. (2012). Women empowerment and participation in economic activities: Indispensable tools for self-reliance and development of Nigerian society. Educational Research and Reviews, 7(1), 10-18.

Ekpe, I. (2011). Women entrepreneurs and economic development in Nigeria: Characteristics for success. International Journal of Business and Social Science, 2(1), 287-291.

Fapohunda, T. M. (2012). Women and the informal sector in Nigeria: Implications for development. British Journal of Arts and Social Sciences, $4(1), 35-45$.

Galbraith, C., \& Schendel, D. (1983). An empirical analysis of strategy types. Strategic Management Journal, 4(2), 153-173.Available at: https://doi.org/10.1002/smj.4250040206.

Goldin, D. Q., \& Kanellakis, P. C. (1995). On similarity queries for time-series data: constraint specification and implementation. In International Conference on Principles and Practice of Constraint Programming (pp. 137-153). Berlin, Heidelberg: Springer.

Grossman, G. M., \& Helpman, E. (1991). Trade, knowledge spillovers, and growth. European Economic Review, 35(2-3), $517-526$.

INEC. (2019). Independent National Electoral Commission 2019 General Election Report. Retrieved from: http://inec.gov.ng.

Laub, J. H., \& Sampson, R. J. (1993). Turning points in the life course: Why change matters to the study of crime. Criminology, 31(3), 301325.Available at: https://doi.org/10.1111/j.1745-9125.1993.tb01132.x.

Moscovitch, A., \& Drover, G. (1981). Inequality: Essays on the political economy of social welfare (Vol. 265, pp. 1-386): University of Toronto Press

NBS. (2013). National Bureau of Statistics 2018 Social Statistics Report. Retrieved from: http://nigerianstat.gov.ng/elibrary.

NBS. (2017). National Bureau of Statistics 2018 Social Statistics Report. Retrieved from: http://nigerianstat.gov.ng/elibrary.

NBS. (2018). National Bureau of Statistics 2018 Social Statistics Report. Retrieved from: $\frac{\text { http://nigerianstat.gov.ng/elibrary. }}{\text { Okafor, E. E. (2011). Youth unemployment and implications for stability of democracy in Nigeria. Journal of Sustainable Development in Africa, }}$ $13(1), 358-373$.

Onwuka, E. M., Ugwu, K. E., Chukwuma, E. D., \& Chijioke, D. E. (2015). Implications of youth unemployment and violent crime on the economic growth. International Journal of Economics, Commerce and Management, United Kingdom, 3(9), 387-403.

Onyinye, N. G., Idenyi, O. S., \& Ifeyinwa, A. C. (2017). Effect of capital formation on economic growth in Nigeria. Asian Journal of Economics, Business and Accounting, 5(1), 1-16. 
Osawe, C. O. (2015). Increase wave of violent crime and insecurity: A threat to socio-economic development in Nigeria. Journal of Humanities and Social Science, $20(1), 123-133$.

Pesaran, M. H., Shin, Y., \& Smith, R. P. (1999). Pooled mean group estimation of dynamic heterogeneous panels. Journal of the American Statistical Association, 94(446), 62 1-634.Available at: https://doi.org/10.1080/01621459.1999.10474156.

Pesaran., M. H., Shin, Y., \& Smith, R. J. (2001). Bounds testing approaches to the analysis of level relationships. Journal of Applied Econometrics, 16(3), 289-326.Available at: https://doi.org/10.1002/jae.616.

Rappaport, A. (1986). Creating shareholder value: The new standard for business performance (pp. 1-270): Free Press. The University of Michigan.

Romer, P. M. (1990). Endogenous technological change. Journal of Political Economy, 98(5, Part 2), S71-S102.

Tanimu, B. (2006). Convicts' view of the criminal justice system in Nigeria. the National Question and Some Selected Topical Issues on Nigeria, 294-309.

Todaro, M. (1992). Economics for a developing world (2nd ed.). England: Longman Group, U.K. Limited.

Vazsonyi, A. T., Jiskrova, G. K., Ksinan, A. J., \& Blatný, M. (2016). An empirical test of self-control theory in Roma adolescents. Journal of Criminal Justice, 44, 66-76.Available at: https://doi.org/10.1016/j.jcrimjus.2015.12.004.

Verick, S. (2018). Female labor force participation and development. Italy, and IZA, Germany: The International Training Centre of the ILO.

Wallerstein, N. (1992). Powerlessness, empowerment, and health: implications for health promotion programs. American Journal of Health Promotion, 6(3), 197-205.Available at: https://doi.org/10.4278/0890-1171-6.3.197.

WDI. (2019). The United Nations World Development Indicators. 